\title{
Review: Catherine Russell, Archiveology: Walter Benjamin and Archival Film Practices
}

Marie-Pierre Burquier

https://doi.org/10.15664/fcj.v0i17.2061

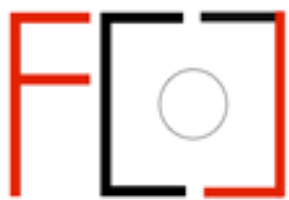

Frames Cinema Journal

ISSN 2053-8812

Issue 17 (Jun 2020)

http://www.framescinemajournal.com

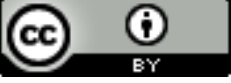




\section{Archiveology: Walter Benjamin and Archival Film Practices \\ By Catherine Russell \\ Duke University Press, 2018}

Reviewed by Marie-Pierre Burquier, Université de Paris

With Archiveology: Walter Benjamin and Archival Film Practices, Catherine Russell supplies an approach based on several key notions from the German philosopher Walter Benjamin - such as memory, document, excavation, historiography, collection and quotation ${ }^{1}-$ in order to understand what they reveal of filmic re-editing practices. From her reading, Russell advances archiveology $^{2}$, a creative and critical methodology that aims to understand cinematographic appropriation, including remix strategies as well as those of recycling and compilation. In order to delimit this new archival science, the theorist analyses a vast array of artistic works, more specifically experimental short movies from the avant-garde and the found footage tradition. Nevertheless, she also considers amateur practices, from essay films to film tributes posted (mainly) on YouTube, all at the junction of experimentation and documentary.

For Russell, archiveology is not a cinematographic genre but an artistic and critical approach of reusing and borrowing existing images that are almost as ancient as the creation of cinema itself and that could take very different forms. It aims to unveil previously unseen meanings, and mainly to awaken or release the dormant energy they contain ${ }^{3}$. Instead of looking only at the images' pasts, it explores their possible futures, their development, in order to renew their comprehension at the present time. Archiveology thus suggests emancipation from the usual chronological relationship with the archive in order to develop an alternative temporality - a heretical one ${ }^{4}$, of the futur antérieur ${ }^{5}$, most capable of displaying an imaginative future of what did not happen or of what could have been the images' futures at the time ${ }^{6}$. These new destinies evolve constantly on account of their reading context and the evolution of historiographical preoccupations.

Expanding on the considerations of her previous book, Experimental Ethnography: The Work of Film in the Age of Video (1999), Russell is interested in the documentary value inherent to found footage practice. If it is known that a movie is always a documentary about its own filming, she shows that fictional images are able to inform a past representation and to show our own uses and our own receptions as soon as they are extracted from their original setting. This capacity to transform cinema into archive is at the heart of her reflection on archiveology. Russell underlines that this transformation is getting easier with the use of digital tools ${ }^{7}$ that involve, by themselves, a change of perspective on an existing representation ${ }^{8}$.

Russell focuses more specifically on imageries that are known to have a coercive background, and thus arouse, for this exact reason, numerous investigations by artists. She lingers especially over classical Hollywood imagery that has been abundantly remade from the 90s on. The artists Matthias Müller and Christoph Girardet, for example, seek through their re-editing to reveal the ideological strategies of domination that are at the heart of this hegemonic iconography, while looking for eventual ways to release the representation. Russell also underlines Jean-Luc Godard's ability, with his Histoire(s) du cinéma (1998), to make visible alternative memories about movies from the past (without any genre distinction); she sees his work as the ultimate example of archiveology.

Following these preliminary considerations, Russell investigates three thematic angles. In the chapter "The Cityscape in Pieces", she looks at the tradition of the urban symphony and the 
city film with Paris 1900 (Nicole Védrès, 1947) and the recent Los Angeles Plays Itself (Thom Andersen, 2003). She shows how urban landscapes are changing materials that echo the form of the archive. They are both composed of different levels that bear the traces of a time that has been lived; they are both documents projected towards their past as well as towards their development. These archiveological movies become archaeological excavation, able to show the density of past representation, especially from urban landscapes that testify to the incessant changes occasioned by modernity.

In the next chapter, entitled "Collecting Images", Russell is interested in the artist as an archivist or an archiveologist. The collector's filmic gesture indeed acquires some anthropological and ethnographic properties, as it is able to record a language or a memory. Her analysis of Hoax Canular (Dominic Gagnon, 2013) testifies to the effective strength of collection: through the assembly of amateur videos from YouTube, the Canadian artist gathers an ensemble of testimonies about a hypothetical upcoming apocalypse, all recorded via personal webcam. This collection reveals new behavioural models and new languages emerging in the face of worldending threats. This comparison between collecting and archiveology leads Russell to develop fascinating considerations about cinephilia (and its supposedly insatiable nature). In the chapter "Phantasmagoria and Critical Cinephilia", she analyses movies by Matthias Müller and Christoph Girardet such as Kristall (2006) and Phoenix Tapes (2000), both made from the obsessive and encyclopaedic ${ }^{9}$ compilation of several typical motifs from Hollywood. She specifically focuses on The Clock (Christian Marclay, 2010), that gathers thousands of shots from the whole history of cinema showing time literally (shots of clocks, watches, clock radio and so on). She thus shows that these cinephilic compilations reveal the documentary underside of the images: they inform the way a filmic motif is working, but more importantly, they inform our relation with time as spectators. By insisting on the circulation of repetitive motifs or by showing movie stars getting old, these fragments show new kinds of historical ruins, while insisting on the ever-changing nature of past images.

The last chapter, "Awakening from the Gendered Archive", demonstrates more particularly the necessity of archiveology in the history of representation. Following Laura Mulvey and Domietta Torlasco ${ }^{10}$, Russell succeeds in showing how this practice manages to reconsider the feminine body. She starts with the assessment that throughout the history of cinema archival investigation has always been gender-based, leading to what Jacques Derrida names the patriarchive $^{11}$ : an archive grappling with an unchangeable authoritarian masculine domiciliation. Looking at these images in an illogical or an incoherent way, away from any preexisting law, found footage films succeed in tearing apart (especially with the help of digital tools) the gendered archive of cinema and open up a new space for feminist readings ${ }^{12}$. Russell notices such a reversal in the famous found footage film Rose Hobart (Joseph Cornell, 1936) as well as in the less-known Three Disappearances of Soad Hosni (Rania Stephan, 2011). These two archiveological movies underline the imprisonment of the actress within the fiction by rendering the mechanisms of representation visible. Through re-editing, they release these icons from their narrative prison and their patriarchal constraints. By seeking to reveal the real women behind the character, they incorporate a feminine subjectivity in the archive and succeed in making possible a new affective relationship between the spectator and the image. More than an aesthetical reformulation, archiveology thus leads to an ideological reinvestment of images from the past, which are now capable of re-politicising present time. 
This book advances a new archival language, with which to renew the history of twentieth-century representation. Archiveology, indeed, enables thinking about the constantly evolving nature of images, by informing not only the way they work but also the way we look at the present time. Russell, thus, seems to support a perpetual re-commitment with images from the past and promotes pursuing the writing of the history of cinema alongside practices of appropriation, through the exploitation of the historiographical properties of archiveology.

\footnotetext{
1 That we find for instance in The Book of Passages.

${ }^{2}$ Walter Benjamin did not coin the neologism archiveology but mentioned it in other terms in a 1931 text entitled "Excavation and Memory." Catherine Russell indicates (p. 11) that she borrowed the term from a 1991 Joel Katz text about From the Pole to the Equator (Yervant Gianikian and Angela Ricci Lucchi, 1990). In addition, Jacques Derrida coined the term archiviologie: "a general and interdisciplinary science of the archive", which may have inspired Russell (cf. Mal d'archive: une impression freudienne [1995], Paris, Galilée, 2008, p. 56).

${ }^{3}$ She borrows this idea from Tom Gunning talking about Film Ist. by Gustav Deutsch. Catherine Russell notes (p. 128) that "For Gunning, the Austrian filmmaker 'cares less about simply making new connections than about awakening energies slumbering in old material"'. For him, Deutsch's collages awaken the dormant energies of past materials ("From Fossils of Time to Cinematic Genesis", pp. 174-175).

${ }^{4}$ Domietta Torlasco (The Heretical Archive: Digital Memory at the End of Film, Minneapolis: University of Minnesota Press, 2013) defines the heretical archive as a disobedient archive, which opposes the meaning it has been assigned.

5 "Future perfect", the ultimate temporality of the archive. Cf. André Habib, "Images du futur antérieur", Vertigo, 2013, n46, pp. 33-34.

${ }^{6}$ Particularly the meaning that the images were not allowed to express clearly, due to censorship or to norms linked to the context of their creation.

${ }^{7}$ In keeping with Laura Mulvey: cf. Au-delà du plaisir visuel : féminisme, énigmes, cinéphilie (2017), a book that gathers several papers published between 1992 and 2015.

${ }^{8}$ Mainly through material change: from analogue to digital.

${ }^{9}$ In The Phoenix Tapes: a list of Alfred Hitchcock's main obsessions. In Kristall: a gathering of a wide array of mirror scenes taken from the whole history of cinema.

${ }^{10}$ Domietta Torlasco, op. cit.

11 In Mal d'archive, 1995.

${ }^{12}$ In order to unveil these heretical films hidden behind the real one, the viewer must be able to adopt a double sight and be aware of what is left out-of-frame or silenced.
} 